\title{
Review of the development of seafarers in Hong Kong
}

\author{
Sik Kwan Tai \\ Department of Logistics and Maritime Studies, \\ The Hong Kong Polytechnic University, \\ Kowloon, Hong Kong
}

\begin{abstract}
Purpose - The purpose of this paper is to review the development of registered seafarers working onboard Hong Kong ships.

Design/methodology/approach - Data obtained from the Marine Department showing the number of registered seafarers from 1960 to 2015.

Findings - The registered seafarers can be observed in three different stages, namely, the peak stage from 1960 to 1982, the declining stage from 1983 to 1996 and the reforming stage from 1997 to 2015.

Originality/value - Very few papers can be found in Hong Kong to review the development of registered seafarers from 1960 to 2015.
\end{abstract}

Keywords Hong Kong ship, Registered seafarers, Seafaring profession, Seafaring training

Paper type General review

\section{Introduction}

Due to the excellent geographical location and the deep sea, the port of Hong Kong has attracted international trade since the nineteenth century. In the twenty-first century, Hong Kong was once the largest container port in the world. International shipping has created jobs for 85,000 people. Every day, there are more than 1,600 ship movements in the Hong Kong harbour. There are more than 17,000 local crafts, such as ferries, yachts and launches in the Hong Kong waters. There are more than 100 high-speed ferries travelling from Hong Kong to/from Macau and China (HK Maritime Museum, 2015). With this background, there had been a lot of people being employed as seafarers in Hong Kong in the ocean-going, river trade or local vessel sectors. However, the number of seafarers has dropped over the years. Moreover, not many young people are interested in joining the seafaring profession.

Although the seafaring profession has a long history in Hong Kong, the importance of local seafarers has not been the same all the time. Through the population of registered seafarers, the seafaring profession since 1960 can be divided into three stages namely, 1960 to 1982, 1983 to 1996 and 1997 to 2015.

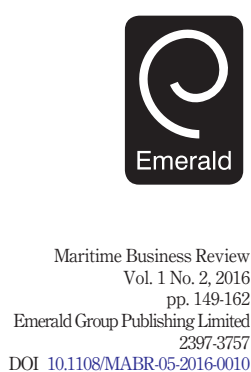

(C) Pacific Star Group Education Foundation

The author is very grateful to Professor LU Chin-Shan to provide valuable suggestions and assistance in the regression analysis. 
MABR

1,2

150

\section{Three stages of development}

Peak stage from 1960 to 1982

In the 1960s, the economy in Hong Kong started to boom. While the employment opportunities onshore were still not too good, it was an ideal career to be a seafarer working onboard ship. Other than the job availability, the financial income was high enough for the livelihood of the whole family (Old Boys Club of the HKSS, 2007). In the 1960s, Hong Kong and Singapore were virtually the sole source of supply of Southeast Asian seafarers (Gorski, 2007).

Thus, in the 1960s and 1970s, there were about 40,000 active seafarers, while the number of registered seafarers were even higher (Old Boys Club of the HKSS, 2007). At the peak stage from 1977 to 1982, as shown in Table I, the number of registered seafarers were always above 82,000 people (Ng, 2010). In 1977, the number was 82,477 and in 1982, it went up to 87,424 (Old Boys Club of the HKSS, 2007). However, the active seafarers could be as high as 50,000. In those years, the actual positions available were about 30,000 . At the same time, about 25 per cent of the registered seafarers were on leave or waiting for new contracts (Old Boys Club of the HKSS, 2007).

\section{Declining stage from 1983 to 1996}

The 1979 (or second) oil crisis was due to the decreased oil output in the wake of the Iranian Revolution. This crisis started a new round of severe recession in the world economy, causing a slump in shipping demand. The world seaborne trade of dry cargoes dropped for two consecutive years - 1982 and 1983 (Chen et al., 2014). The effect in Hong Kong was that less seafarers were employed. Due to the unemployment, many seafarers left the seafaring profession and engaged in other shore-based jobs. In the 1980s, there were about 5,000 people in officer grade. The actual number of seafarers on employment went down to about 20,000 (Old Boys Club of the HKSS, 2007).

Since 1987, the economy of Hong Kong became better. Although sea-going jobs were available, shipowners had difficulty in recruiting enough Hong Kong seafarers to fill-up the vacancies due to the loss of seafarers during the recession. The first declining factor was that, to solve the manpower problem, shipowners had to employ more seafarers from China, Philippines, India and other neighbouring countries to replace Hong Kong seafarers (Old Boys Club of the HKSS, 2007).

Another factor of the declining trend of Hong Kong seafarers was the new entry requirements in the seafaring profession. In 1978, the International Maritime Organization (IMO) introduced the International Convention on Standards of Training, Certification and Watchkeeping for Seafarers (STCW), and it was entered into force in 1984. It was the first time that there were basic requirements on training, certification and watchkeeping for seafarers on an international level, rather than to be decided by individual governments.

The STCW had an impact in Hong Kong because the training courses provided in Hong Kong, in accordance to the standards of the STCW, were not enough to meet the

Table I.

Record of registered

\begin{tabular}{lcccccc}
\hline Year & 1977 & 1978 & 1979 & 1980 & 1981 & 1982 \\
\hline Registered seafarers & 82,477 & 83,918 & 85,136 & 86,236 & 87,038 & 87,424
\end{tabular}

seafarers

Source: Old Boys Club of the HKSS (2007) 
demand. A solution drawn by the Hong Kong Seamen's Union was to ask the Chinese Government to allow some Hong Kong seafarers to be trained and obtain the certification in China (Old Boys Club of the HKSS, 2007). Although the Chinese Government agreed to help, it could not stop the downtrend of new entrants joining the seafaring profession in Hong Kong. In 1977, there were 1,838 new entrants. In 1980, there were only 1,416 new entrants. In 1983, it went down to 1,072. In 1996, the figure was only 266. (Old Boys Club of the HKSS, 2007).

Due to the sharp drop in new entrants in the seafaring profession, a generation gap had clearly appeared. According to the data obtained from the marine department, in 1983, there were 84,493 registered seafarers. The figure dropped to 66,936 in 1990. It further dropped to 64,255 in 1996. For the same period, in 1990, there were 3,890 seafarers serving on ocean-going vessels. In 1996, the figure dropped to 873.

Facing the generation gap issue, several seamen organizations in Hong Kong joined together to form the Maritime Professional Promotion Federation (MPPF) in 1993 to lobby the Hong Kong Government to encourage young people to join the seafaring profession and set up new policies to attract shipowners to employ more Hong Kong seafarers. The Hong Kong Government realized the seriousness of the problem. The Marine Department, thus, carried out a campaign by visiting secondary schools to encourage young people to join the seafaring profession (Old Boys Club of the HKSS, 2007).

\section{Reforming stage from 1997 to 2015}

In September 1996, a new law concerning seafarers was introduced in Hong Kong. Merchant Shipping (Recruiting of Seamen) Ordinance (Cap 135) was repealed by Merchant Shipping (Seafarers) Ordinance (Cap 478). As a result, all Hong Kong seafarers had to re-register on or before 1 September 1997, to keep the status 'employed' to work on sea-going vessels or costal-going ships. Moreover, section 10(3) of Cap 478 provides a new condition for the registration of seafarer that, in any continuous three-year period of registration, a registered seafarer is required to be employed as a seafarer for an aggregate period of not less than 18 months. According to section 10(5) of Cap 478, it is a criminal offence to employ a person who has not a valid seafarer registration as a seafarer.

As a result of the new law, many inactive seafarers either did not bother to re-register themselves as they had already left the seafaring profession or were not eligible to re-register under the new law. This could explain why the number of registered seafarers in Hong Kong suddenly dropped from more than 60,000 in 1996 to just barely over 3,000 in 1997 under the re-registration scheme, as shown in Table II. The number of registered seafarers was kept between 3,000 and 6,000 between 1997 and 2015. On the other hand, the Hong Kong shipping industry was not doing well. In 1997, the Hong Kong registered ships had a record low of 5,470,000 gross tonnages (Old Boys Club of the HKSS, 2007). The manpower demand was lower than the previous years.

One of the reasons that young people were not interested in joining the seafaring profession was that the financial reward was lower than many onshore jobs. Through the mechanism provided by the Maritime Labour Convention 2006, the International Labour Organization (ILO) has a mechanism to set the basic wages of seafarers. As a reference, the current minimum monthly basic wage of seafarers, as on 1 January 2016, is US\$614, which is equivalent to HK\$4,787. Many shipowners will pay only the
Seafarers in Hong Kong 


\begin{tabular}{|c|c|c|c|c|c|}
\hline $\begin{array}{l}\text { MABR } \\
1,2\end{array}$ & $\begin{array}{l}\text { At the end } \\
\text { of year }\end{array}$ & $\begin{array}{l}\text { No. of seafarers } \\
\text { registered in } \\
\text { Hong Kong }\end{array}$ & $\begin{array}{l}\text { Serving onboard } \\
\text { ocean-going } \\
\text { vessels }(\mathrm{A})\end{array}$ & $\begin{array}{l}\text { Serving onboard } \\
\text { river-trade } \\
\text { vessels (B) }\end{array}$ & $\begin{array}{c}\text { Total } \\
(\mathrm{A}+\mathrm{B})\end{array}$ \\
\hline \multirow{4}{*}{152} & 1996 & 64,255 & 873 & NA & 873 \\
\hline & 1997 & 3,119 & 724 & NA & 724 \\
\hline & 1998 & 3,414 & 492 & 917 & 1,409 \\
\hline & 1999 & 3,491 & 378 & 853 & 1,240 \\
\hline \multirow{16}{*}{$\begin{array}{l}\text { Table II. } \\
\text { Statistical figures of } \\
\text { seafarers registered }\end{array}$} & 2000 & 3,611 & 326 & 901 & 1,227 \\
\hline & 2001 & 3,701 & 263 & 895 & 1,158 \\
\hline & 2002 & 3,799 & 208 & 949 & 1,157 \\
\hline & 2003 & 3,911 & 207 & 944 & 1,151 \\
\hline & 2004 & 4,055 & 201 & 1,023 & 1,224 \\
\hline & 2005 & 4,170 & 179 & 1,063 & 1,242 \\
\hline & 2006 & 4,285 & 159 & 1,059 & 1,218 \\
\hline & 2007 & 4,498 & 160 & 1,275 & 1,435 \\
\hline & 2008 & 4,874 & 177 & 1,570 & 1,747 \\
\hline & 2009 & 5,083 & 147 & 1,446 & 1,593 \\
\hline & 2010 & 5,221 & 165 & 1,307 & 1,472 \\
\hline & 2011 & 5,346 & 149 & 1,307 & 1,456 \\
\hline & 2012 & 5,512 & 171 & 1,332 & 1,503 \\
\hline & 2013 & 5,648 & 179 & 1,290 & 1,469 \\
\hline & 2014 & 5,851 & 191 & 1,311 & 1,502 \\
\hline & 2015 & 6,003 & 173 & 1,326 & 1,499 \\
\hline
\end{tabular}

in Hong Kong from 1996 to 2015

Sources: Mercantile Marine Office Marine Department (Hong Kong); Yip (2016)

minimum wages to seafarers, especially to cadets who are still under training to be qualified as Class Three Officers. Moreover, the life at sea was always thought to be boring and dangerous. The seafarer welfares were not as good as those onshore jobs.

To attract more young people to join the seafaring profession, the Hong Kong Government introduced the Sea-going Training Incentive Scheme in 2014 to financially subsidise the incomes of sea cadets. The scheme is administered by the Marine Department. Under the scheme, a deck/engineer cadet may receive, as an incentive, $\$ 6,000$ per month during the training period.

\section{The present situation of Hong Kong seafarers}

Lack of supply of Hong Kong seafarers

Since late 1980s, many Hong Kong seafarers had given up the seafaring profession and found new shore-based jobs. On the other hand, new entrants were very few. As a result, Hong Kong shipowners had difficulty to recruit enough local seafarers to manage their ships, especially ocean-going vessels. The supply and demand was imbalanced. Hong Kong shipowners thus had to turn to other Asian countries for the supply of seafarers.

Moreover, when the economy of Hong Kong became better and better, the costs of employing Hong Kong seafarers were higher (Gorski, 2007). The wages to seafarers would be higher than the median wages to other employees. Therefore, it would be cheaper for Hong Kong shipowners to employ seafarers from Asian countries (Old Boys Club of the HKSS, 2007). 
Specifically, Figure 1 illustrates the relationships between Gross Domestic Production (GDP) per capita in terms of US\$ and the number of seafarers in Hong Kong between 1997 and 2015. In general, Figure 1 shows that the GDP per capital had a negative influence on the number of seafarers in sea-going. A regression approach that used GDP per capita as an explanatory variable could be considered with a regression equation of the form:

$$
\operatorname{Ln} Y_{t}=\alpha+\beta \operatorname{Ln} \mathrm{X}_{\mathrm{t}}+\mathrm{e}_{\mathrm{t}}
$$

where $\operatorname{Ln} Y_{t}$ is the natural logarithm of the number of seafarers annually, $\operatorname{Ln} \mathrm{X}_{\mathrm{t}}$ is the natural logarithm of an indicator variable (i.e. GDP per capita), $\beta$ is a coefficient for the indicator variable and $e_{t}$ is an error term. For the period 1997 to 2015 , results for the regression is:

$$
\operatorname{Ln} Y_{t}=\alpha+\beta \operatorname{Ln} X_{t}
$$

where per cent $\Delta$ number of seafarer $=16.23-0.455$ per cent $\Delta$ GDP per capita;

(3.151) (-2.105).

$R^{2}=0.455$, adjusted $R^{2}=0.207, F=4.430$, standard error of the estimate $=0.40$.

The results indicated that the increase of salary in land, such as GDP per capita, will decrease the number of seafarers in sea-going.

Although shipowners are able to pay less in employing non-Hong Kong seafarers, it does not mean that all Hong Kong seafarers are receiving high wages. The situation is different in different rankings of seafarers. It is true that masters and officers are earning better than shore-based jobs in general. As shown in Figures 2 and 3, in 2015, the monthly wages to a Hong Kong master working on a sea-going cargo ship is more than $\$ 64,000$ and to a master working onboard a river-trade vessel is more than $\$ 60,000$ (Yip, 2016).

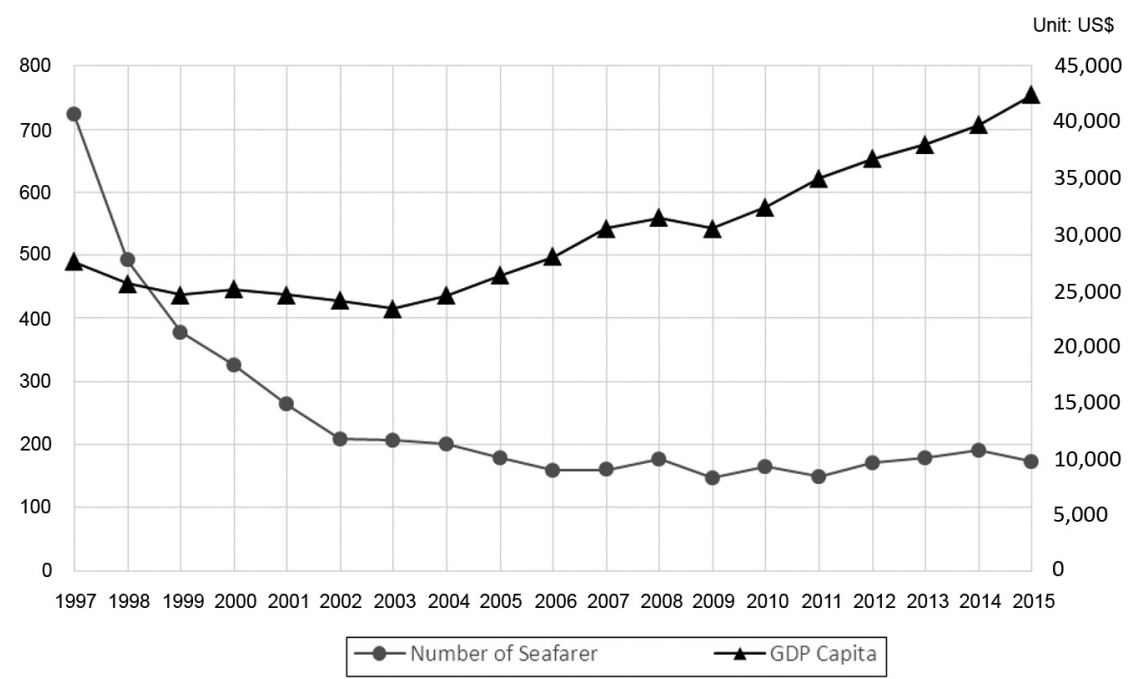

Figure 1.

The number of seafarers and GDP per capita (USD) in Hong Kong between 1997 and 2015 


\section{MABR}

1,2

\section{4}

\section{Figure 2.}

Average monthly gross wages of Hong Kong seafarers employed to serve on sea-going ships for the year 2015 (173 seafarers)
Figure 3.

Average monthly gross wages of Hong Kong seafarers employed on river-trade ships in 2015 (1,326 Seafarers)

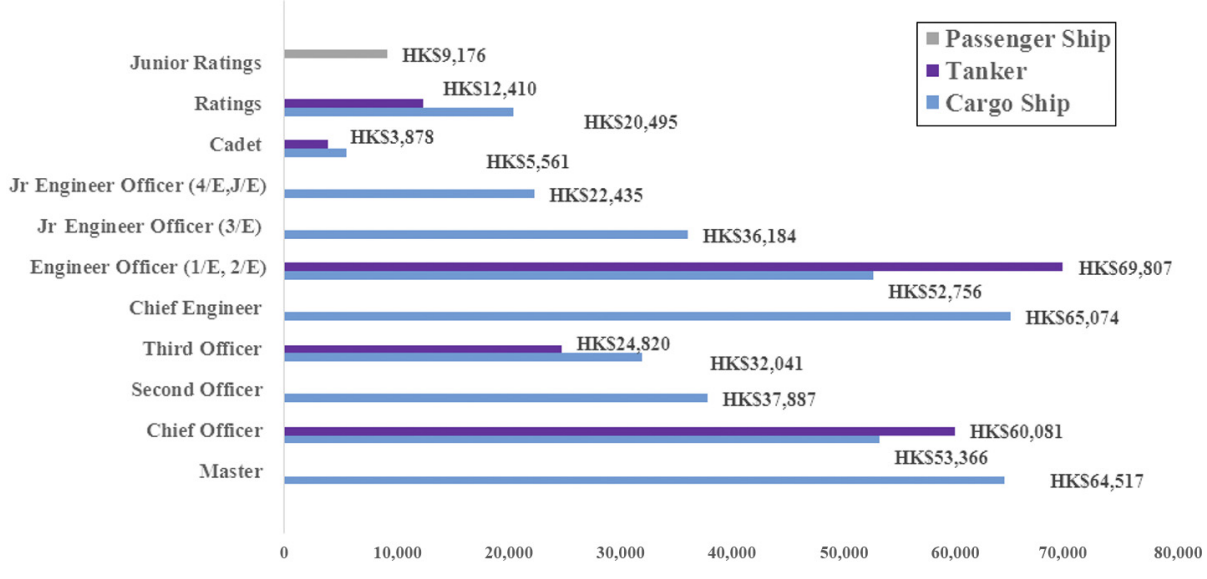

Sources: Mercantile Marine Office; Marine Department (Hong Kong); Yip (2016)

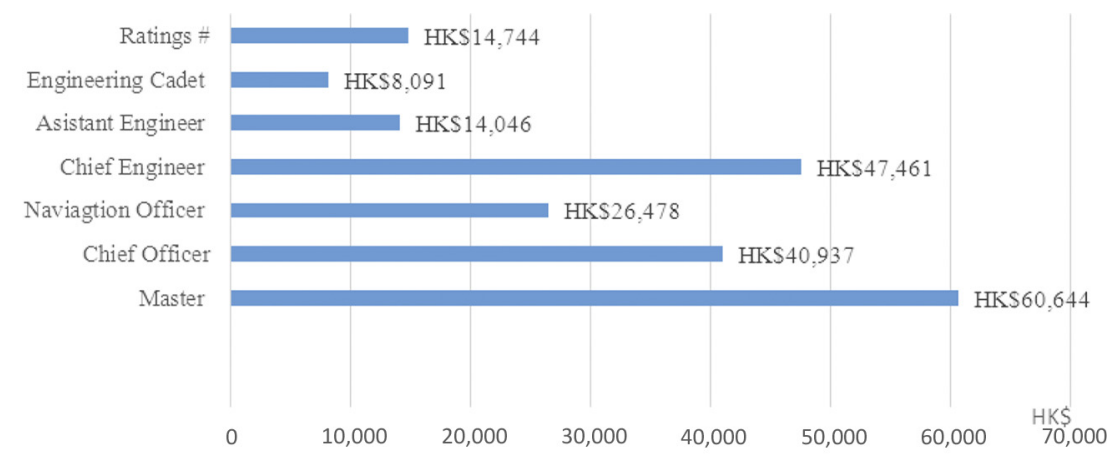

Sources: Mercantile Marine Office; Marine Department (Hong Kong); Yip (2016)

On the other hand, the wages to ratings are fairly low according to the Hong Kong earning standard, although they are receiving higher than the minimum wages set by the ILO as at January 2016 which is US\$614 (about HK\$4,787) for a junior rating. As shown in Figure 2, the junior ratings working on passenger ships are receiving monthly wages of $\$ 9,176$. While the ratings on tanker ships are only receiving $\$ 12,410$, the ratings on cargo ships are receiving $\$ 20,495$. (Yip, 2016) However, the payments to cadets are really poor. As shown in Figure 2 , cadets on cargo ships are only receiving $\$ 5,561$. Those young people who are working onshore are better paid for their jobs. As shown in Table III, employees in manufacturing are receiving wages of $\$ 14,900$ per month, land transport of $\$ 16,800$ and construction of $\$ 20,000$.

Shipowners were happy to employ more and more seafarers from the "new labour supply countries", such as China, Philippines and India to replace the Hong Kong seafarers (Wu, 2011). In 2015, as shown in Table IV, 2,477 ships were registered in Hong Kong. Most of them, i.e. 2,247 ships, were ocean-going ships. Hong Kong shipowners 
were generally employing non-Hong Kong seafarers to manage their ships. As shown in Table V, more than 32,000 Chinese seafarers were employed on Hong Kong registered ships. (Yip, 2016) A Chinese seafarer is only receiving a monthly wage of about $\$ 5,000$ (Hsdhw.com, 2016). They constituted of the largest number of non-Hong Kong seafarers. Philippines came second with 7,457 seafarers and India came third with 7,430 seafarers. At the same time, only 123 Hong Kong seafarers had been employed on Hong Kong flagged ships.

Seafarers in Hong Kong

\section{Generation gap of Hong Kong seafarers}

Since the STCW had taken effect in 1984, only well-trained people were qualified to take up the job of seafarers. The Hong Kong Government had set up the Nautical Maritime Training Board (NMTC) in 1979 with the purpose of reviewing the arrangements of the training facilities and institutes. However, the NMTC had not done a good job. In fact, the supply of training courses to seafarers was not enough to meet the demand. Even if young people wanted to join the seafaring profession, they had difficulties in getting a place to be trained as qualified seafarers. Moreover, the incomes from working onboard ships were not so attractive than those from working onshore. Thus, both the inadequacy of training and unattractive income were the discouraging factors for young people to join the seafaring profession. As a result, there was a sharp drop in the number of new and young seafarers joining the seafaring profession. In 1996, the seafaring profession had only 266 entrants. Between 1997 and 2000, the figures were 266, 250, 209, 87 and 121 respectively (Old Boys Club of the HKSS, 2007).

On the other hand, many experienced seafarers were inactive or retired. They had given up the seafaring job of working onboard ships and found shore-based jobs. One of the popular jobs was to be construction workers because of the construction boom and better wages (Old Boys Club of the HKSS, 2007).

\begin{tabular}{lcc}
\hline Selected industry section & May-June 2014 & May-June 2015 \\
\hline Construction & $\$ 18,300$ & $\$ 20,000$ \\
Land transport & $\$ 16,000$ & $\$ 16,800$ \\
Import \& export trade & $\$ 16,000$ & $\$ 16,500$ \\
Other transportation, storage \& courier services & $\$ 15,400$ & $\$ 16,200$ \\
Manufacturing & $\$ 14,300$ & $\$ 14,900$
\end{tabular}

Source: Census and statistics department

Table III. Median monthly wage by selected industry section in Hong Kong (HK\$)

\begin{tabular}{lcccccccc}
\hline & \multicolumn{2}{c}{ Ocean-going } & \multicolumn{2}{c}{ River trade } & \multicolumn{2}{c}{ Local services } & \multicolumn{2}{c}{ Overall } \\
Yo. of & Gross & No. of & Gross & No. of & Gross & No. of & Gross \\
Year (December) & ships & tonnage & ships & tonnage & ships & tonnage & ships & tonnage \\
\hline 2014 & 2,138 & $92,657,573$ & 77 & 46,781 & 158 & 78,009 & 2,373 & $92,782,363$ \\
2015 & 2,247 & $102,169,557$ & 77 & 46,783 & 153 & 76,682 & 2,477 & $102,293,022$
\end{tabular}

Source: Marine Department

Table IV. Number and gross tonnages of ships registered in Hong Kong 


\section{MABR}

1,2

156

\begin{tabular}{lrrr}
\hline & Officer & Rating & Total \\
\hline PRC & 14,204 & 18,672 & 32,876 \\
India & 3,488 & 3,969 & 7,457 \\
Philippines & 2,397 & 5,033 & 7,430 \\
Ukraine & 578 & 207 & 785 \\
Myanmar & 279 & 380 & 659 \\
Sri Lanka & 297 & 341 & 638 \\
Russia & 241 & 24 & 265 \\
Bangladesh & 100 & 62 & 162 \\
Indonesia & 24 & 135 & 159 \\
UK & 114 & 21 & 135 \\
Hong Kong & 77 & 46 & 123 \\
Taiwan & 56 & 16 & 72 \\
Croatia & 47 & 6 & 53 \\
Singapore & 18 & 3 & 21 \\
Australia & 17 & 1 & 18 \\
Korea & 16 & 2 & 18 \\
Others & 384 & 240 & 624 \\
Total & 22,337 & 29,158 & 51,495
\end{tabular}

Table V.

Distribution of crew nationality of Hong Kong registered ships as on 31 December 2015

Sources: Mercantile Marine Office, Marine Department (Hong Kong); Yip (2016)

By the end of 2015, the generation gap was more serious in ocean-going Hong Kong seafarers than those working onboard river-trade vessels. As shown in Figure 4, in ocean-going vessels, more than 62 per cent of the seafarers are over 50 years old. On the other hand, only 19 per cent of the seafarers are below 30 years old. (Yip, 2016) As shown in Figure 5, for the river-trade vessels, 27 per cent of the seafarers are over 51 years old, and only 20 per cent are below 30 years old. (Yip, 2016) Young people are more willing to work onboard river-trade vessels because they need not work outside Hong Kong for a long period of time.

Figure 4.

Age of seafarers registered in Hong Kong for ocean-going vessels as on 31 December 2015 (4,425 seafarers)
[CATEGORY

NAME][PERCENTAGE]

Over 60 years old $49 \%$

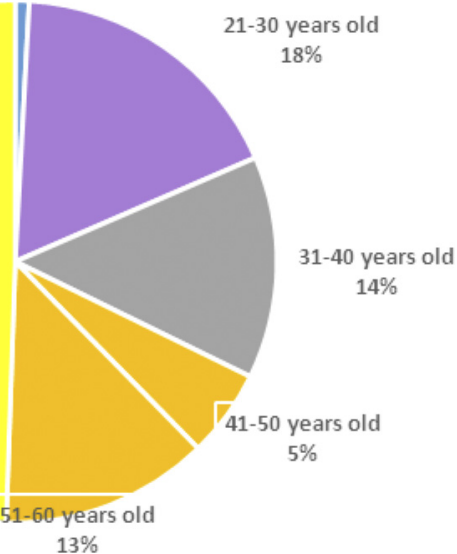




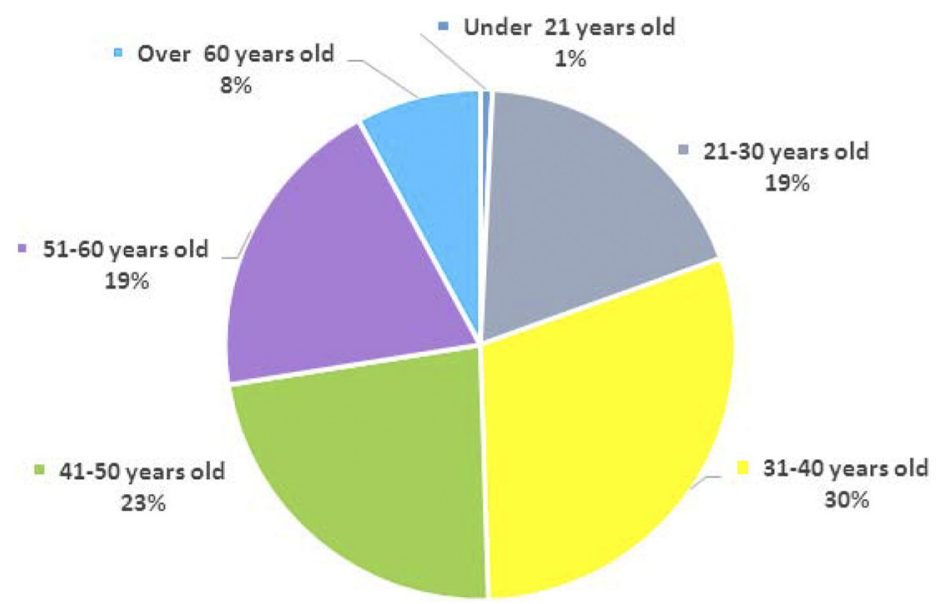

Sources: Mercantile Marine Office; Marine Department (Hong Kong); Yip (2016)
Seafarers in Hong Kong

\section{Supply of Hong Kong seafarers}

There are several educational institutions which have a special function to prepare young people to join the seafaring profession. They are the Hong Kong Sea School (HKSS), the Maritime Services Training Institute (MSTI), the Department of Logistics and Maritime Studies of the Hong Kong Polytechnic University. In addition, the Department of Mechanical Engineering of the Hong Kong Polytechnic University, the Hong Kong University of Science and Technology and the University of Hong Kong are also approved by the marine department.

Hong Kong Sea School (HKSS) (named in 1959, formerly known as “Boys' camp”). HKSS was founded by Mr. Brook Antony Bernacchi in January 1946. Originally, it was a special school to provide education to orphans, under-privileged children and "street-boys". The HKSS prepared them to be junior seafarers to earn for their livings.

The students of the HKSS were educated with nautical knowledge. After their graduation, many students went onboard to work as junior able-bodied seamen and sat for seamen's certification examinations. They generally climbed up the seafaring career ladder and became higher-ranked seafarers. With the acquisition of Certificate of Competency, some of them joined the marine department and became top-level officials and others became instructors, master mariners, pilots and marine superintendents. (Yip, 2016)

In 1969, converted by the Education Department, the HKSS became a full-day junior secondary school. In 1993, it became the first practical school in Hong Kong and vocational subjects were introduced in the curriculum. The school started mainstreaming with effect from 2001 but retained its naval traditions by including drills and parades, as well as maintaining the provision of boarding service.

The HKSS is now refocusing on the training of potential seafarers to cater for the needs of the local maritime industry. Junior students have to study the subject of nautical studies and senior students are required to study the subject of "seafarers". 
MABR

1,2
The HKSS encourages its senior students to attend pre-sea certificate classes held by the MSTI. Interested students can apply for a place to attend training classes of the six pre-sea certificates which are pre-requisites to work onboard in accordance with STCW (2010) of the IMO. The courses are partly sponsored by the HKSS (Yip, 2016).

Hong Kong Institute of Vocational Education (IVE). The Vocational Training Council (VTC) was established in 1982. It is the largest vocational and professional education and training provider in Hong Kong. IVE is one of the 13 member institutions of VTC.

VTC is the major training provider for maritime services employees (including seafarers) in Hong Kong. It supplies a large number of graduates for the maritime services industry. The graduates of the pre-employment courses in the year 2014 were 194 (MSTB, 2014).

The IVE centre at Tsing Yi, jointly with the MSTI, is offering a Higher Diploma in Maritime Studies (HDMS). It is a two-year full time programme providing students with professional maritime knowledge, practical skills for shipboard operations and training on practices in maritime industries for the purpose of preparing them to pursue further study and development in the seafaring career and marine-related sectors. Graduates can serve in the merchant navy as deck cadets.

Four centres of IVE at Chai Wan, Lee Wai Lee, Tsing Yi and Tuen Mun are offering a Higher Diploma in Mechanical Engineering. It is a two-year full time programme providing students with the necessary knowledge and skills to become competent professionals in mechanical engineering. Upon completion of the programme, graduates will have acquired the necessary academic, technical and management knowledge and skills, which enable them to secure employment in the technical/operational/market development and follow-up services functions in the field of mechanical engineering. Graduates can serve in the merchant navy as engineer cadets.

Maritime Services Training Institute (MSTI). The Seamen's Training Centre was set up in 1983. In 1988, it was renamed as the MSTI and located at Tai Lam Chung, Tuen Mun. To satisfy the manpower demands and training needs of the maritime industry in Hong Kong, MSTI provides a wide range of training courses for new entrants. It also works closely with Marine Department and other trade associations/unions to meet the demands for in-services short courses and launches the appropriate courses in a timely manner (MSTB, 2014). Its planned training capacity is approximately 5,000 trainees per year.

To cope with the manpower need and staff development of the industry, MSTI also provides industry participants with a wide variety of skills upgrading courses. MSTI also works closely with the Marine Department and other trade associations/unions to meet the demands for in-services short courses and launches the appropriate courses in a timely manner.

To fulfil the training and certification requirements for seafarers, mid-stream and shore-based workers, the MSTI offers two full-time pre-employment courses, namely, the two-year HDMS and 23-week Certificate for Junior General Purpose Ratings (CJGPR).

At present, the MSTI is the sole approved training provider in Hong Kong for various mandatory safety familiarization and basic training courses as set out in the STCW Code, Merchant Shipping Regulations, Shipping and Port Control Regulations (Cap 313A) and Factories and Industrial Undertakings Regulation (Cap 59A), such as 
personal survival techniques, fire prevention, fire fighting, proficiency in survival craft and rescue boats, radar navigation, plotting and use of Automatic Radar Plotting Aids (ARPA) and Global Maritime Distress and Safety System (GMDSS) general operator certificate etc.

Department of Logistics and Maritime Studies, the Hong Kong Polytechnic University (LMS). The Hong Kong Polytechnic University has a long history of maritime education. In 1937, it was named the Government Trade School. In 1947, the school became the Hong Kong Technical College. In 1972, the Hong Kong Polytechnic was established. Its mandate was to provide application-oriented education to meet the community's need for professional manpower resources. The institute assumed full university status in 1994 and changed its name to "The Hong Kong Polytechnic University".

Maritime education was housed in the Department of Nautical Studies. After several changes in the name of the department, it is now known as the Department of Logistics and Maritime Studies (LMS). Currently, LMS is offering two programmes, which may prepare the graduates to enter into the seafaring profession as deck cadets. These are the four-year full-time programme in BBA (Hons) in International Shipping and Transport Logistics (BBA-ISTL) (www.lms.polyu.edu.hk/en/academic-programmes/bba-hd/ 4-year-istl/) and the two-year full-time programme in Higher Diploma in International Transport Logistics (HD-ITL). Students in these programmes can take nautical subjects, such as maritime introduction, foundation for nautical studies and marine navigation and meteorology.

All the graduates are eligible to register as deck cadets to join the sea-going ships. They must have sea time experience for at least one year before they can take the examination for the third officer.

Department of Mechanical Engineering. The three universities mentioned above are offering four year full time bachelor degree programmes in mechanical engineering. All the graduates are eligible to register as engineer cadets to join the sea-going ships.

\section{Conclusion and recommendations}

Based on the throughput in 2014, the largest container port worldwide is Shanghai and is followed by Singapore, Shenzhen and Hong Kong. Hong Kong is still a busy and important maritime port with a throughput of 22.3 million twenty-foot equivalent units (TEUs) (Statista.com).

Seafaring profession is a good career in Hong Kong. "Seafaring is an excellent career choice for those with a sense of adventure, those who enjoy travel and are conscientious about responsibility". (HK Maritime Museum, 2015) In fact, seafaring is an international profession. The seafarer qualification is internationally accepted. Thus, the job availability is not only on Hong Kong ships, but also on any ships of all nationalities. Compared with the old days, the safety, facilities and welfares for working onboard ships have greatly improved.

Moreover, after obtaining sufficient sea experience, there are many more chances in different maritime-related onshore jobs. Thus, it is really an ideal profession to be considered by young people, especially for those graduates from maritime-related programmes offered by different educational institutes in Hong Kong.

However, not many young people are actually joining or employed in the seafaring profession, despite all the works done by the Hong Kong Government and maritime 
MABR

1,2

160

organisations in Hong Kong. The following recommendations should be considered to attract more young people to become seafarers:

First, the most important consideration is the seafarers' wages, especially for deck/ engineer cadets. Cadets are future officers on ships. However, they are only paid more or less the minimum wages set by the ILO which is less than $\$ 5,000$. Despite the $\$ 6,000$ incentive subsidies from the Hong Kong Government, they are still receiving less than $\$ 12,000$ per month which is less than the average income of a graduate who may easily have $\$ 14,000$ or more from an onshore job. Thus, the Hong Kong Government should continue the Sea-going Training Incentive Scheme and increase the subsidies to $\$ 8,000$ at least, so that cadets can receive monthly income in the region of $\$ 14,000$.

Second, the job opportunity must be certain and sufficient. If the shipowners of Hong Kong registered ships continue their practice to employ non-Hong Kong seafarers with lower costs, young seafarers would not have a good future in their career ladder. The Hong Kong Government should have new policies, such as tax incentive or wage subsidies etc., to encourage shipowners to have priority employment of Hong Kong seafarers. If the said soft policies are not workable, the Hong Kong Government may consider passing new laws to force shipowners to employ at least 50 per cent of Hong Kong seafarers on Hong Kong ships. Moreover, the Marine Department should take active role in helping seafarers to find jobs. In the website of the Marine Department, a new page should be created to provide employment information on Hong Kong and non-Hong Kong ships.

Third, high-level training courses should be offered in Hong Kong. Currently, those institutes in Hong Kong who are providing seafarer training courses are only offering basic training courses up to cadet level. Courses to prepare third officers and higher are not offered in Hong Kong. Young officers have to travel to Singapore, Australia or the UK to study and prepare for the qualification examinations. Thus, the Hong Kong Government should invest in the MSTI or the Hong Kong Polytechnic University, so that these institutes can provide such training courses for third officers and higher rankings.

Fourth, the public should be educated to have a positive understanding of the life at sea of seafarers. In Taiwan, despite the high income of seafarers who are paid at least NT $\$ 100,000$ per month, while bachelor degree graduates are paid about NT $\$ 30,000$ only, it is still difficult for Taiwan shipowners to recruit young seafarers. (Taihainetcom, 2016) The main reason is that seafarers have to work away from home for few months at a time. In Hong Kong, many people still have the impression that the working conditions of seafarers are poor and dangerous. In fact, after the taken effect of the Seafarers' Bill of Rights or Maritime Labour Convention 2006 and other International Transport Workers' Federation (ITF) Conventions, the working conditions, welfares and safety on ships have been improved. Some ships also provide internet for seafarers to keep contact with their relatives and friends at home. The Hong Kong Government should carry out a large campaign targeted at secondary school leavers to let them have a better understanding of the working conditions, welfares and safety of seafarers working onboard ships. It is a good example that the Taiwanese Government has successfully produced two mini-films of 12 minutes to pass such a message to young people. The films can be easily accessed on the internet through the YouTube. Thus, the Hong Kong Government may produce similar mini-films to be watched by the public. Cadets and young seafarers may be invited to speak to the school leavers. 
Fifth, the MPPF has done a very good job in the promotion and recruitment of young people to join the seafaring profession. They are also providing useful trainings to the young people in interview skills, English language and correct attitude in the career at sea. However, the MPPF is a volunteer group without enough sources to get in touch with a bigger population of young people. The Hong Kong Government should recognise the importance of its work and provide greater financial subsidies to it.

Hopefully, in the near future, more young people would be interested in joining the seafaring profession and thus keep Hong Kong as an important maritime port.

\section{References}

Chen, S., Meersman, H., Voorde, E. and Frouws, K. (2014), Modelling and Forecasting in Dry Bulk Shipping, Informa Law, New York, NY.

Gorski, R. (2007), Maritime Labour: Contributions to the History of Work at Sea, 1500-2000, Amsterdam University Press, Amsterdam.

Hong Kong Maritime Museum (2015), “25 June: International Day of the Seafarer”.

Hsdhw.com (2016), "Where should Chinese seafarers to go to? (in Chinese)", Quick News, available at: http://news.hsdhw.com/324931/ (accessed 25 May 2016).

Maritime Services Training Board, Vocational Training Council (2014), “2014 Manpower Survey of Maritime Services Industry".

Mercantile Marine Office, Marine Department (2012), "Annual survey of wages of Hong Kong seafarers as at 31 December 2011”, Seafarers' Advisory Board Paper No. 1/2012.

Mercantile Marine Office, Marine Department (2013), "Annual survey of wages of Hong Kong registered seafarers as at 31 December 2012”, Seafarers' Advisory Board Paper No. 1/2013.

Mercantile Marine Office, Marine Department (2014), "Annual survey of wages of Hong Kong registered seafarers as at 31 December 2013”, Seafarers' Advisory Board Paper No. 1/2014.

Mercantile Marine Office, Marine Department (2015), “Annual survey of wages of Hong Kong registered seafarers as at 31 December 2014”, Seafarers' Advisory Board Paper No. 1/2015.

Mercantile Marine Office, Marine Department (2016), "Annual survey of wages of Hong Kong seafarers as at 31 December 2015”, Seafarers’ Advisory Board Paper No. 1/2016.

Ng, S.H. (2010), Labour Law in Hong Kong, Kluwer Law International, New York, NY.

Old Boys Club of the HK Sea School (2007), The Legend of Hong Kong Sea School (in Chinese), Ming Wen Publication, Salt Lake City.

Taihainetcom (2016), "Why don't Taiwanese young men 'go to sea'? (in Chinese)", Strait News, p. 22, available at: http://epaper.taihainet.com/html/20160303/hxdb593450.html (accessed 25 May 2016).

Wu, A.L. (2011), "Sailing on a Neoliberal sea: multinational seafarers on container ships", Hong Kong Anthropologist, Vol. 5 No. 1, pp. 1-20.

Yip, Y.P. (2016), "Development of the career of seafarers in HK”, Maritime Business Insight, Vol. 4 No. 2, pp. 3-21.

\section{Further reading}

Census and Statistics Department (2016), “2015 Report on Annual Earnings and Hours Survey”. Days on the Bay Co Ltd (2012), The Port of Hong Kong Handbook and Directory 2012, Days on the Bay, London.

International Labour Office (1998), Maritime Labour Conventions and Recommendations, 4th ed., International Labour Office, Geneve. 
MABR 1,2

International Labour Office (2004), The Global Seafarer: Living and Working Conditions in a Globalized Industry, International Labour Organization, Geneve.

Lam, K. (2016), "Why Hong Kong does not have High Quality Maritime science training (in Chinese)", Seaview, Vol. 11 No. 3, pp. 23-24.

Li, K.X., Yin, J., Luo, M. and Wang, J. (2014), "Leading factors in job satisfaction of Chinese seaarers", International Journal of Shipping and Transport Logistics, Vol. 6 No. 6, pp. 680-693.

Liu, H.T. and Fang, F.L. (2005), "The forthcoming shortage of seafarers: human resources policy arguments in Taiwan (in Chinese)", Maritime Quarterly, Vol. 14 No. 2, pp. 21-40.

Lu, H.K. and Chen, T.C. (2016), "Internationalized development of Taiwan seafarers (in Chinese)", Chinese Seamen's Monthly News, Vol. 74 No. 7, pp. 31-40.

Maritime Services Training Board, Vocational Training Council (2012), “2012 Manpower Survey of Maritime Services Industry".

National Taiwan Ocean University (2014), "Taiwan Marine professionals cultivation forum”, available at: tmec.ntou.edu.tw/ezfiles/31/1031/img/308/128581450.pdf (accessed 25 May 2016).

\section{Corresponding author}

Sik Kwan Tai can be contacted at: sktai@polyu.edu.hk

For instructions on how to order reprints of this article, please visit our website:

www.emeraldgrouppublishing.com/licensing/reprints.htm

Or contact us for further details: permissions@emeraldinsight.com 